\title{
KONDISI TEGAKAN Palaquium amboinense Burk. PADA PETAK 4.3 DI HUTAN PENDIDIKAN ANGGORI MANOKWARI
}

\section{(Standing Tree Condition of Palaquium amboinense Burk. at 4.3 Grid Plotted Design of Anggori Educational Forest in Manokwari)}

\author{
Silas Kayoi ${ }^{1}$ dan Descalo Worabai ${ }^{1 凶}$ \\ Jurusan Kehutanan, Fakultas Kehutanan Universitas Papua Manokwari, Papua Barat, \\ 98314. Tlp/Fax: +62986211065 . \\ Penulis Korespondensi: Email: devilboeper@yahoo.com \\ Diterima: 2 Feb 2019| Disetujui: 27 Feb 2019
}

\begin{abstract}
Abstrak
Penelitian ini bertujuan untuk mengetahui kondisi tegakan Palaquium amboinense Burk., dan faktor kerusakan fisik yang mengakibatkan terhambatnya pertumbuhan pada petak 4.3 di lokasi Hutan Pendidikan Anggori. Untuk memperoleh data, jalur dan plot pengamatan dibuat yang selanjutnya di setiap plot, diamati seluruh jenis $P$. Amboinense. Hasil penelitian menunjukkan bahwa terdapat 95 pohon, dimana 3 jenis dikategorikan sebagai pohon mati, 70 pohon dalam kondisi tidak sehat dan 22 tegakan yang masuk dalam kategori sehat. Kondisi tegakan $P$. amboinense yang tidak sehat diakibat serangan dari organisme pengganggu tanaman seperti penyakit yang antara lain kanker dan tumor pada batang utama. Selain itu terdapat juga serangan hawar daun, bercak daun, karat daun dan lubang pada daun. Sementara liana dan gulma juga teridentifikasi pada tegakan $P$. amboinense yang selanjutnya dapat memperhambat laju pertumbuhan tegakan $P$. Amboinense.
\end{abstract}

Kata kunci: Palaquium amboinense, hutan pendidikan anggori, liana, hama, gulma

\begin{abstract}
This study aims to notice Palaquium amboinense Burk. standing condition and physical damaging factors that potentially causing the slowdown of the growth at 4.3 grid of Anggori Educational Forest. In order to obtain data, track and plot are established to subsequently identify all P. Amboinense as well as its physical damages that found in each plot. The result pointed out that there were ninety-two trees, in which 3 individuals had identified as dead trees, seventy trees under unhealthy conditions and the other twenty-two trees were in the healthy condition. These unhealthy trees were likely caused by organism attacks which then initiated tree diseases such as cancer and tumor that found in the main stem of P. Amboinense. Besides, other diseases found in the leaves such as pathogen attack, spotting around the leaf, rust leaf, and small holes around eth surface of the leaf. Another damaging external factor also found such as lianas and weeds that stick into the main stem of $P$. amboinense and in the surrounding growing area.
\end{abstract}

Keywords: Palaquium amboinense, Anggori Educational Forest, liana, pest, weed 


\section{PENDAHULUAN}

Indonesia adalah salah satu negara yang mempunyai hutan tropis terluas dan terkaya di Dunia. Hutan tropis ini merupakan habitat flora dan fauna yang kelimpahannya tidak tertandingi oleh negara lain dengan luas yang sama. Pembangunan yang terjadi secara besarbesaran dan berlangsung cepat mengakibatkan berkuranganya keanekaragaman hayati dalam bentuk gangguan pada ekosistem (Lekitoo et al. 2017). Pembangunan hutan tanaman merupakan suatu kegiatan penting untuk memenuhi berbagi fungsi produksi dan pelindung. Pembangunan hutan tanam umunya dilakukan dengan pola tanaman satu jenis (monokultur), sehingga hutan tanaman merupakan suatu ekologi binaan dengan budi daya pohon hutan. Pola penanaman monokultur tersebut rentan terhadap kerusakan hutan yang disebab'kan baik oleh faktor biotik maupun abiotik. Oleh karena itu tindakan perlindungan hutan tidak dapat dianggap sebagai satu penyelesaian masalah kerusakan sesaat, atau hanya merupakan tindakan darurat, melainkan lebih diarahkan untuk mengenali dan mengevaluasi semua sumber kerusakan yang potensial agar kerusakan yang besar dapat dihindari.

Selain pembangunan hutan tanaman, salah satu aplikasi kegiatan yang dapat dilakukan guna menjaga ketersediaan sumberdaya genetik dan keanekaragaman hayati adalah arboretum. Arboretum adalah tempat pohon-pohon dikembangbiakkan dan ditanam, baik secara individu maupun berupa tegakan untuk tujuan pendidikan dan ilmu pengetahuan (Shadily 1980). Selanjutnya, Soetisna (1985) menyatakan bahwa arboretum adalah kebun dengan jenis tumbuhan lokal untuk tujuan pelestarian dan pendidikan. Menurut Handayani (2015), Pengembangan arboretum umumnya tidak hanya berfungsi sebagai tempat koleksi tanaman, namun juga mencakup fungsi lainnya seperti sarana penelitian, praktikum, sumberdaya plasma nutfah (bank genetik), koleksi tanaman obat, tempat hidup beberapa satwa liar, perlindungan sumber matamata air, dan lain sebagainya. Pengembangan lahan seperti ini dapat mempunyai tujuan menjadi suatu model penghijauan terpola untuk sarana pembelajaran tentang konservasi dan keanekaragaman hayati. Selain itu, dapat juga untuk meningkatkan ruang terbuka hijau, menyediakan detail referensi bidang tumbuhan; menyediakan laboratorium lapang untuk pendidikan Botani, Ekologi, Konservasi, dan Hortikultura; melestarikan spesies tumbuhan endemik dan alami; mempunyai nilai konservasi, estetika, dan ekonomis menyediakan contoh; serta sebagai media pembelajaran. Keberadaan arboretum dapat pula dipakai sebagai tempat rekreasi yang mendidik bagi masyarakat. Penelitian ini bertujuan untuk mengetahui kondisi tegakan dan faktor kerusakan fisik yang mengakibatkan terhambatnya pertumbuhan tegakan Palaquium amboinense Burk. pada petak 4.3 di hutan pendidikan Anggori. Dengan demikian penelitian ini dapat memberikan informasi tentang kondisi terkini hutan pendidikan Anggori khususnya pada tegakan Palaquium amboinense Burk.

\section{METODE PENELITIAN}

Penelitian ini dilakukan pada petak 4.3 yang berlokasi pada Arboretum Hutan Pendidikan Fakultas Kehutanan Universitas Papua, Kabupaten 
Manokwari dengan lamanya waktu penelitian sekitar 3 minggu pada bulan November Tahun 2018. Yang menjadi objek dalam penelitian ini adalah tegakan Palaquium amboinense Burk. yang tumbuh pada petak tanam 4.3 di Hutan Pendidikan Unipa Anggori Manokwari.

\section{Tahapan Penelitian}

\section{Pembuatan jalur}

Penelitian dilakukan dengan membuat 2 dua jalur pengamatan dalam petak pengamatan seluas 50 meter $\times 50$ meter. Hal ini dilakukan untuk mempermudah pengamatan. Setiap jalur terdiri dari 2 plot pengamatan sehingga terdapat 6 plot pengamatan. Plot pengamatan dibuat seluas $20 \mathrm{~m} \times 20 \mathrm{~m}$ untuk pohon dengan mendata keseluruhan pohon nyatoh $(P$. amboinense) yang ada (sensus) kemudian, $1 \mathrm{~m} \times 1 \mathrm{~m}$ untuk mendata jumlah semai nyatoh di bawah tegakan.

\section{Pengambilan Data}

Pengambilan data berupa pengamatan terhadap kondisi tegakan $P$. amboinense. Data yang diambil berdasarkan beberapa data variabel yang telah ditentukan antara lain:

1. Diameter pohon yang diukur setinggi dada dengan menggunakan phy band.
2. Tinggi total pohon dan tinggi bebas cabang diukur dengan menggunakan hagameter.

3. Kesehatan pohon berupa jenis-jenis penyakit, hama, gulma dan liana pada pohon.

4. Potensi permudaan $P$. amboinense. meliputi data jumlah individu semai nyatoh dalam plot pengamatan.

\section{Pengolahan dan Analisa Data}

Data hasil pengukuran, selanjutnya dilakukan analisis statistik deskriptif. Data - data hasil analisa, disajikan dalam bentuk tabel dan gambar.

\section{HASIL DAN PEMBAHASAN}

\section{Kondisi Tegakan}

Berdasarkan pengamatan dilapangan pada tegakan $P$. amboinense. pada Arboretum Anggori petak 4.3 dengan luas $50 \mathrm{~m} \times 50 \mathrm{~m}(0,25 \mathrm{ha})$, terdapat 95 pohon, dimana 3jenis dikategorikan sebagai pohon mati atau pohon busuk yang tidak memiliki diameter, 70 pohon tidak sehat dan 22 tegakan yang masuk kategori sehat. Kondisi pada tegakan $P$. amboinense tidak sehat diduga akibat serangan dari organisme pengganggu tanaman seperti penyakit, hama, liana dan gulma yang ditemukan di bawah tegakan.

Tabel 1. Kondisi pohon pada tegakan P. amboinense

\begin{tabular}{ccccc}
\hline $\begin{array}{c}\text { Jumlah Pohon } \\
\text { pada petak 4.3 }\end{array}$ & $\begin{array}{c}\text { Jumlah pohon } \\
\text { yang sehat }\end{array}$ & $\begin{array}{c}\text { Jumlah Pohon } \\
\text { yang tidak sehat }\end{array}$ & $\begin{array}{c}\text { Jumlah pohon } \\
\text { yang mati }\end{array}$ & $\begin{array}{c}\text { Jumlah } \\
\text { Semai }\end{array}$ \\
\hline 95 & 22 & 70 & 3 & 26 \\
\hline
\end{tabular}

Diameter merupakan salah satu parameter pertumbuhan pohon yang harus diukur selain tinggi pohon. Dengan pengukuran diameter dan tinggi, kita dapat mengetahui potensi tegakan suatu komunitas hutan. Berdasarkan hasil pengukuran tinggi dan diameter, rata-rata diameter $P$. amboinense adalah $46,97 \mathrm{~cm}$, sedangkan untuk rata-rata tinggi (tinggi total) $31,11 \mathrm{~m}$. Besarnya diameter pohon 
dipengaruhi kualitas tempat tumbuh dan usia dari pohon tersebut. Semakin subur tempat tumbuh maka pertumbuhan pohon akan semakin baik, hal ini ditunjukkan dengan besarnya ukuran diameter pohon tersebut. Demikian pula pengaruh usia pohon dengan ukuran diameter pohon, semakin tua umur pohon maka diameternya akan lebih besar (Fina 2013).

Tabel 2. Parameter tegakan P. amboinense

\begin{tabular}{lccc}
\hline \multicolumn{1}{c}{ Variabel Pertumbuhan } & Ukuran terkecil & Rata-rata & Ukuran terbesar \\
\hline Diameter setinggi dada $(\mathrm{cm})$ & $20 \mathrm{~cm}$ & $46,97 \mathrm{~cm}$ & $85 \mathrm{~cm}$ \\
Tinggi bebas cabang $(\mathrm{m})$ & $7 \mathrm{~m}$ & $21,72 \mathrm{~m}$ & $44 \mathrm{~m}$ \\
Tinggi total $(\mathrm{m})$ & $15 \mathrm{~m}$ & $31,11 \mathrm{~m}$ & $43 \mathrm{~m}$ \\
\hline
\end{tabular}

Berdasarkan data sebaran pohon menurut kelas diameter, jumlah pohon terbanyak berada pada kelas diameter 37
- $44 \mathrm{~cm}$ yaitu 20 pohon diikuti kelas diameter $\leq 28 \mathrm{~cm}$ yaitu 19 pohon, seperti tersaji pada tabel 3 .

Tabel 3. Sebaran jumlah pohon berdasarkan kelas diameter pohon

\begin{tabular}{ccc} 
No & Kelas diameter $(\mathrm{cm})$ & $\sum$ Pohon \\
\hline 1 & $\leq 28$ & 19 \\
2 & $29-36$ & 8 \\
3 & $37-44$ & 20 \\
4 & $45-52$ & 11 \\
5 & $53-60$ & 10 \\
6 & $61-68$ & 10 \\
7 & $69-76$ & 5 \\
8 & $>77$ & 9 \\
\hline & Total & 92 \\
\hline
\end{tabular}

Pertumbuhan diameter dipengaruhi oleh aktivitas fotosistesis, dimana pertumbuhan diameter berlangsung apabila hasil fotosintesis seperti respirasi, penggantian daun, pertumbuhan akar dan tinggi telah terpenuhi (Davis dan Jhonson 1987). Setidaknya terdapat tiga faktor lingkungan (tempat tumbuh) dan satu faktor genetik (intern) yang sangat nyata berpengaruh terhadap pertumbuhan diameter maupun tinggi, yaitu kandungan nutrien mineral tanah, kelembaban tanah dan cahaya matahari, serta keseimbangan sifat genetik antara pertumbuhan tinggi dan diameter suatu pohon (Davis dan Jhonson 1987).

Dari hasil pengamatan terlihat bahwa untuk tinggi bebas cabang terbanyak pada kisaran ketinggian 21 - 30 meter dimana terdapat 45 pohon diikuti tinggi bebas cabang pohon pada ketinggian $11-20$ meter dengan jumlah pohon 38 . Sedangkan untuk data tinggi total pohon berada pada kisaran 31 - 35 meter dengan jumlah pohon 30. Sama seperti pertumbuhan diameter, untuk 
pertumbuhan tinggi biasanya selain faktor cahaya yang mempengaruhi pertambahan tinggi tanaman tetapi juga tingkat kerapatan tegakan. Menurut Baker (1950) dalam Kapisa (1984) bahwa tegakan dengan kerapatan $75 \%$ akan mengurangi pertumbuhan tinggi pohon bebas cabang tersebut, disamping diameter batang dapat bertambah sebanding dengan tinggi pohon. Sehingga menurut Baker (1950), untuk lokasi dataran rendah ataupun dataran tinggi dan pegunungan, pohonnya mempunyai tinggi berbeda-beda dengan demikian kurva diameter batang pohon akan menyesuaikan dengan lokasi tempat tumbuhnya. Maka dapat diasumsikan bahwa ketinggian pohon erat sekali hubungannya dengan diameter pohon, artinya pohon bertambah tinggi berarti akan menambah diameter batang pohon.

\section{Permudaan}

Potensi permudaan yang diamati dalam tegakan pengamatan tidak menunjukan jumlah yang melimpah. Jumlah individu semai $P$. amboinense pada saat pengamatan yaitu 26 semai dimana rata-rata semai yang dijumpai pada plot pengamatan berkisar antara 2 sampai 5 individu per plot pengamatan. Sidiyasa dkk. (2006), semakin tinggi diameter pohon maka semakin sedikit pula jumlah individunya. Hal ini sejalan dengan kondisi yang ditemui di lapangan, dimana rata-rata tanaman $P$. amboinense ini masih mengalami kondisi bertumbuh baik dari pertambahan diameter maupun tinggi. Untuk hutan tanaman, biasanya pertumbuhan diameter mengikuti grafik berbentuk huruf S (sigmoid), karena pada mulanya tumbuh agak lambat, kemudian cepat lalu menurun. Menurut Hani dan Effendi (2009) anakan yang tumbuh di bawah tegakan akan mengalami pertumbuhan yang kurang optimal. Karena akan mengalami persaingan yang cukup ketat dalam mendapatkan unsur hara dan cahaya.

\section{Kesehatan Tegakan}

Mengetahui status kesehatan tegakan pohon secara periodik sangat penting untuk menentukan tindakan silvikultur pada sebuah pertanaman. Informasi kesehatan tegakan ini harus diperoleh melalui metoda penilaian dengan menggunakan prosedur dan kriteria yang tepat. Status kondisi kesehatan hutan perlu dipantau secara berkesinambungan dari waktu ke waktu. Sistem pemantauan berguna untuk mengevaluasi kesehatan hutan serta memberikan informasi kepada pemilik lahan dan pihak pengelola sumberdaya hutan tentang status ekologi hutan, perubahan apa yang terjadi, apa saja agen penyebab perubahan yang terdapat dalam ekosistem, apakah perubahan-perubahan mengindikasikan tren, apa hasil yang diharapkan jika tren tersebut terus berlanjut, dan apa efeknya pada keputusan manajemen terkait kondisi yang ada. Informasi - informasi tersebut dapat diperoleh melalui pelaksanaan berkala pemantauan kondisi ekosistem hutan. Menurut Dunn (1999), dalam penentuan tingkat kesehatan suatu tegakan pohon ada beberapa faktor yang dinilai yaitu tapak pohon, kondisi tajuk, kerusakan pohon dan indikator tanah. Pada penelitian ini, kami hanya mendata setiap serangan dari organisme penggangu tanaman yang disebabkan oleh penyakit; hama; maupun liana.

\section{Penyakit}

Jenis-jenis penyakit yang ditemukan pada tegakan $P$. amboinense antara lain: 


\section{Kanker Batang}

Penyakit kanker batang terjadi karena batang luka yang disebabkan oleh beberapa faktor misalnya kebakaran, tertimpa, pohon roboh, cakaran, atau gigitan satwa liar dan aktivitas manusia (Firdara dkk. 2009). Penyakit kanker batang pada tegakan $P$. amboinense terjadi pada pohon bagian bawah pangkal dan bagian atas pohon.

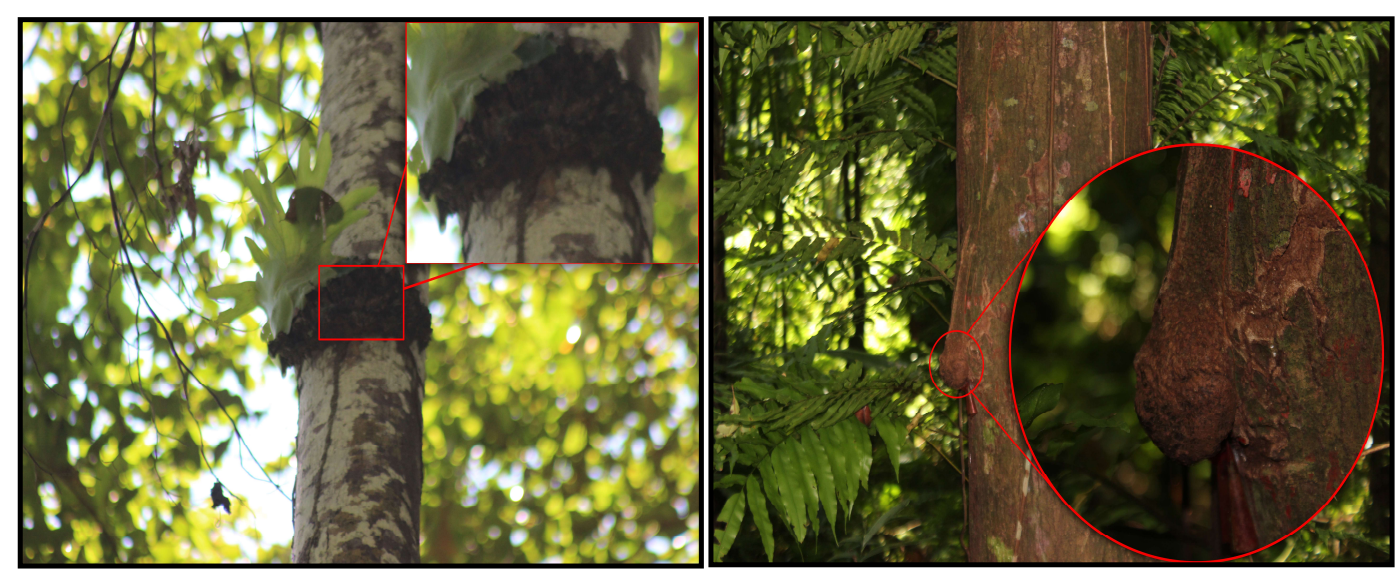

Gambar 1. Jenis dan bentuk penampakan penyakit pada tegakan $P$. amboinense. Gambar kiri jenis penyakit kanker batang pada tegakan berdiri, gambar kanan jenis tumor batang pada tegakan P. amboinense.

\section{Tumor Batang}

Penyakit tumor batang terjadi pada bagian batang, sepanjang batang yang terserang mengalami pembengkakan, ada yang berupa bintil-bintil atau bisul-bisul dan ada juga yang melebihi ukuran biasa (hipertrofi), lama kelamaan pertumbuhan pohon menjadi terhambat (Firdara dkk. 2009).

Penyakit busuk batang terjadi pada bagian batang karena matinya sel-sel atau jaringan-jaringan pada batang. Menurut Widyastuti dkk. (1998), penyakit busuk disebabkan karena rusaknya sel-sel atau jaringan-jaringan.

\section{Hawar Daun}

Penyakit hawar daun terjadi karena sel-sel yang terdapat pada jaringan daun mengalami kematian, pada bagian tersebut warnanya berubah menjadi coklat atau hitam yang ukurannya lebih lebar dari bercak daun (Firdara dkk. 2009).

\section{Bercak Daun}

Penyakit bercak daun dicirikan dengan adanya bercak-bercak warna coklat (nekrosis), berbentuk bulat bersegi-segi sampai lonjong, dikelilingi oleh klorosis berwarna pucat. Nekrosis terjadi di permukaan bawah dan atas daun (Firdara dkk. 2009).

\section{Karat Daun}

Penyakit karat daun terjadi pada permukaan atas dan bawah daun yang ditandai dengan bercak-bercak nekrosis berwarna coklat pada daun, berbentuk agak bersegi-segi (Firdara dkk. 2009). 

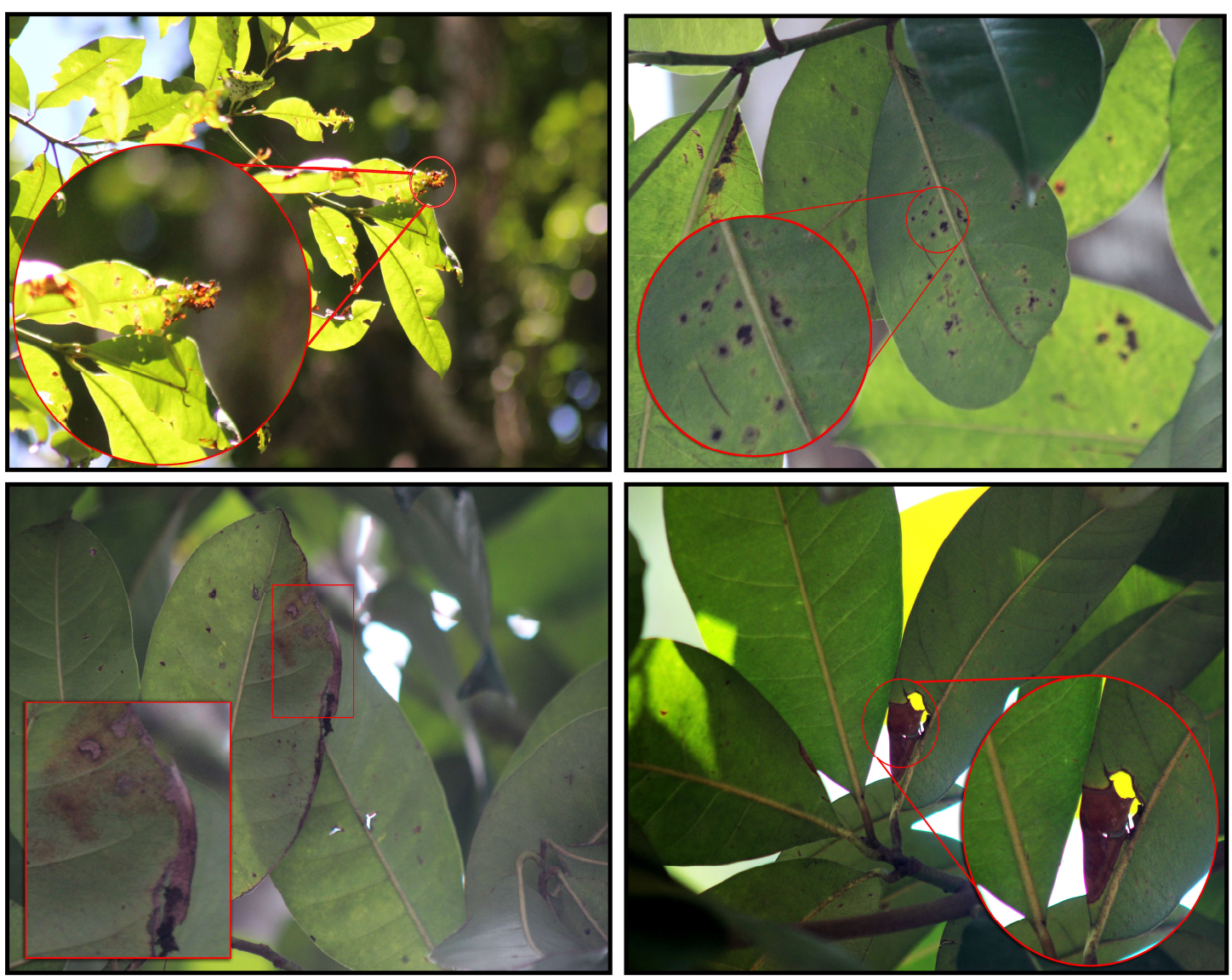

Gambar 2. Bentuk-bentuk cacat pada daun tegakan berdiri P. amboinense; Gambar kiri atas merupakan jenis penyakit hawar daun, Gambar kanan atas mengindikasikan bercak-bercak pada daun, Gambar kiri bawah adalah indikasi cacat karat daun dan Gambar kanan bawah terindikasi lubang-lubang pada daun.

\section{Lubang Daun}

Penyakit lubang daun dicirikan dengan adanya lubang-lubang pada daun dengan ukuran bervariasi akibat diserang hama. Hama tersebut menyerang helaian daun antara tepi dan tulang daun primer dan ada juga yang menyerang dari tepi helaian daun, tulang daun primer dan tulang daun sekunder (Firdara dkk. 2009).

\section{Liana}

Liana merupakan spesies tumbuhan merambat. Tumbuhan ini memiliki batang yang tidak beraturan dan lemah, sehingga tidak mampu mendukung tajuknya (Indriyanto 2012 dalam Welda dkk. 2017). Pada kondisi tegakan $P$. amboinense. terdapat banyak liana yang mempengaruhi tingkat pertumbuhan tegakan, pada tingkat pancang, hingga pohon. Jenis-jenis liana yang dapat menyerang tegakan dapat dilihat pada gambar dibawah ini. 


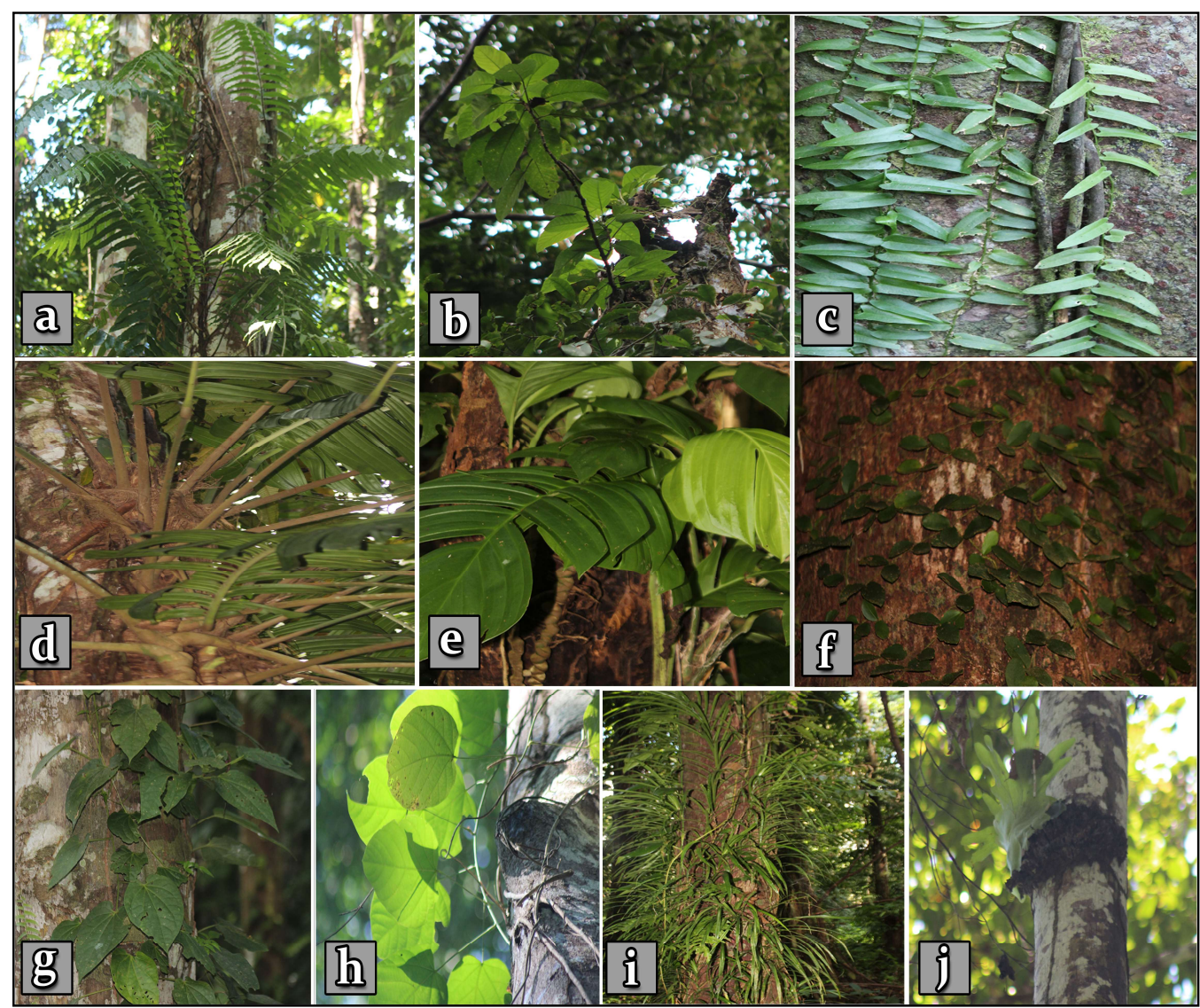

Gambar 3. a). Stnochlaena palustri, b). Ficus sp., c). Vitis sp., d). Rapihdophora korthalsi., e). Philodendron sp., f). Cyrtandra sp., g). Piper macropiper., h). Anamirta cocculus., i). Freycinetia sp., j). Platycerium bifurcatum.

\section{Hama}

Berdasarkan pengamatan dilapangan pada tegakan $P$. amboinense., terdapat beberapa hama yaitu: rayap dan semut. Jenis rayap yang dapat menyerang tegakan $P$. amboinense adalah rayap pohon dan rayap tanah. Rayap termasuk ke dalam ordo Isoptera dari famili
Termitidae. Organisme ini memiliki tubuh yang lunak dan berwarna terang. Kebanyakan dijumpai pada banyak tempat seperti di hutan, pekarangan, kebun dan bahkan di dalam rumah (Kambhampati dan Eggleton 2000). Makanan utamanya adalah kayu dan bahan-bahan dari selulosa lain serta jamur (Subekti 2012). 

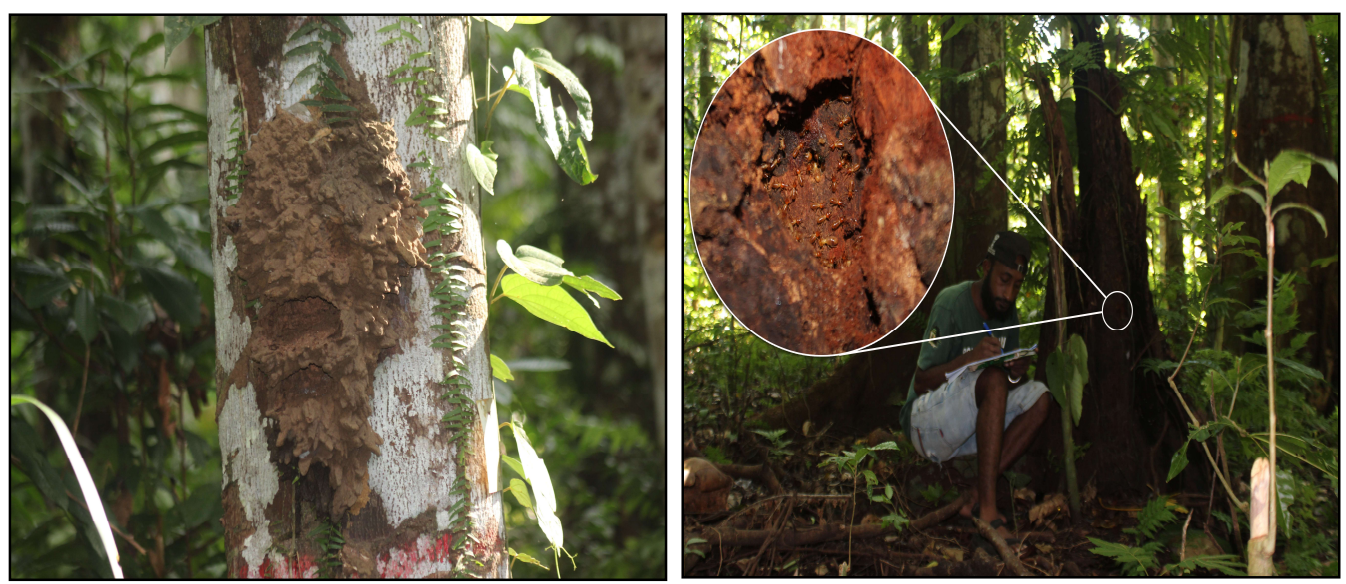

Gambar 4. Sisi kiri adalah bentuk okupasi batang pohon oeh rayap pohon Neotermes tectonae. Sisi kanan bentuk dan proses kerusakan tegakan oleh rayap Glyptotermes dilatatus.

\section{DAFTAR PUSTAKA}

Baker. 1950. Principles of silviculture. McGraw-Hill Book Company, inc. New York.

Davis LS and KN, Jhonson. 1987. Forest management. Third Edition. McGrawHill Book Company, New York.

Dunn PH. 1999. Forest health monitoring field methods guide USDA Forest Service, Washington D.C. National Forest Health Monitoring Program Research Triangle Park, NC 27709.

Fina. 2013. Metode inventore hutan. Pustaka Pelajar. Yogyakarta.

Firdara EK, Mardji D dan Simarangkir BDAS. 2009. Identifikasi jenis penyakit pada lima jenis Dipterocarpaceae di Kalampangan Zone Kalimantan Tengah. Jurnal Kehutanan Tropika Humida, 2 (1): 29 $-42$.

Hani A dan Effendi R. 2009. Potensi permudaan alam tingkat semai (Khaya antotecha) di Hutan Penelitian Pasir Hantap, Sukabumi, Jawa Barat. Bogor.
Mitra Hutan Tanaman, Vol 4 (2): 4956.

Kambhampati S and Eggleton P. 2000. Taxonomy and phylogeny of termites. In Abe, T., Bignell, D.E, dan Higashi, M. 2000. Termites: Evolution, Sociality, Symbioses, Ecology. Dordecht: Kluwer Academic. pp: 1-23.

Kapisa N. 1984. Studi tentang hubungan antara tinggi bebas cabang, diameter dan volume pohon Matoa (Pometia spp.), kayu Besi (Intsia spp.) dan Nyatoh (Palaquium spp.) di areal hutan Mandopi Kesatuan Pemangku Hutan Manokwari. [Skripsi]. Manokwari. Fakultas Pertanian Universitas Negeri Cenderawasih. (Tidak diterbitkan).

Lekitoo K, Peday HFZ, Panambe N and Cabuy RL. 2017. Ecological and ethnobotanical facet of 'Kelapa Hutan' (Pandanus spp.) and perspectives towards its existence and benefit. International Journal of Botany, 13: 103-114. 
Shadily H. 1980. Ensiklopedi Indonesia. Ichtiar Baru-van Hoeve. Jakarta. 33 hal.

Sidiyasa K, Zakaria dan Iwan R. 2006. Hutan desa Setulang dan Sengayan Malinau Kalimantan Timur: Potensi dan identifikasi langkah-langkah perlindungan dalam rangka pengelolaannya secara lestari. Bogor (ID): Central for International Forestry Research.

Soetisna U. 1985. Pertemuan Penang: Bangkitnya kebun-kebun botani di daerah tropika. Jakarta. 36 hal. (Tidak dipublikasikan).
Subekti N. 2010. Karakteristik populasi rayap tanah Coptotermes sp. (Blattodea: Rhinotermitidae) dan dampak serangannya. Jurnal Biosaintifika, 2 (2): 110-114.

Welda N, Arisandy DA dan Widiya M. 2017. Inventarisasi tumbuhan liana yang terdapat di Bukit Sulap Kota Lubuk linggau.

http://mahasiswa.mipastkipllg.com/rep ository/ARTIKEL\%20NOVA.pdf

Diakses 28 Januari 2019.

Widyastuti SM, Sumardi dan Harjono. 1998. Patologi hutan. Gadjah Mada University Press, Yogyakarta. 